\title{
Anticancer effect of SZC017, a novel derivative of oleanolic acid, on human gastric cancer cells
}

\author{
LEI GAO ${ }^{1}$, ZHEN XU $^{1}$, YAN WANG $^{1}$, BIN SUN $^{1}$, ZHICHENG SONG $^{2}$, BINING YANG $^{1}$, XU LIU ${ }^{1}$,

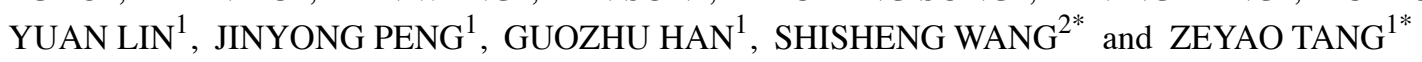 \\ ${ }^{1}$ Department of Pharmacology, Dalian Medical University, Dalian, Liaoning 116044; ${ }^{2}$ College of Pharmaceutical \\ Science and Technology, Dalian University of Technology, Dalian, Liaoning 116024, P.R. China
}

Received August 24, 2015; Accepted October 6, 2015

DOI: $10.3892 /$ or.2015.4447

\begin{abstract}
Oleanolic acid (OA) and its several derivatives possess chemopreventive and chemotherapeutic functions against a series of cancer types. Many chemotherapeutic compounds are effective in improving the quality of life and prolonging the survival of patients with gastric cancer, therefore progress in the treatment of gastric cancer, especially the anticancer effects of OA derivatives must be achieved. The inhibitory effect of SZC017, a newly synthesized derivative of OA, on cell viability was determined by MTT assay. Furthermore, flow cytometry, transmission electron microscopy, and western blot analysis revealed that the inhibition of cell viability by $\mathrm{OA}$ was mediated by triggering the intrinsic apoptosis of gastric cancer cells, and inducing $S$ phase arrest of SGC7901 cells. Mechanistically, SZC017 was effective against gastric cancer cells via inhibiting Akt/NF- $\kappa \mathrm{B}$ signaling and topoisomerase I and II $\alpha$ proteins. Taken together, our data indicate that SZC017 may be a potential chemotherapeutic agent against gastric cancer cells.
\end{abstract}

\section{Introduction}

The burden of cancer has shifted from more developed countries to less developed countries, and gastric cancer accounts for $57 \%$ of cancer cases and $65 \%$ of cancer-related deaths worldwide. Gastric cancer, which has the highest incidence rate in Eastern Asia (particularly in Japan, Korea and China),

Correspondence to: Professor Zeyao Tang, Department of Pharmacology, Dalian Medical University, 9 West Section, Lvshun South Road, Dalian, Liaoning 116024, P.R. China

E-mail: tangzeyao@aliyun.com

Professor Shisheng Wang, College of Pharmaceutical Science and Technology, Dalian University of Technology, Dalian, Liaoning 116024,P.R. China

E-mail: shishengw@163.com

${ }^{*}$ Contributed equally

Key words: SZC017, oleanolic acid derivative, MGC-803, SGC-7901, apoptosis is the third most commonly diagnosed cancer type and the leading cause of cancer-related death in less developed countries (1). Although many chemotherapeutic compounds have been investigated to improve the quality of life and prolong the survival of patients with gastric cancer, progress in the treatment of gastric cancer is unsatisfactory.

Oleanolic acid (OA) is a ubiquitous pentacyclic triterpenoid compound, which is abundant in dietary and medicinal plants. It has been isolated from more than 1,600 plant species in nature. It is considered to be a basic molecule for chemical modifications due to its pharmacological activities, availability, and low production costs. Several portions of OA, such as the C-3 hydroxy, the C-12-C-13 double bond and the C-28 carboxylic acid, have led to a series of new synthetic derivatives. It also serves as an aglycone of triterpenoid saponins that is linked with sugar chains to form glycosides. Both OA and its derivatives possess several biological activities, including hepatoprotective effects, antioxidant, anti-inflammatory, antiviral and anticancer activities (2-4). Many OA derivatives have shown their chemopreventive and chemotherapeutic functions among a series of cancer types, such as acute myeloid leukemia, breast cancer and prostate cancer (5-7). However, reports concerning the anticancer effects and mechanism of OA derivatives on gastric cancer are sparse.

In the present study, SZC017, a derivative of OA, was newly synthesized and evaluated in regards to its anticancer activity against gastric cancer cells. Furthermore, we aimed to ascertain whether the inhibitory effect of SZC017 on cell viability was mediated by inducing apoptosis and cell cycle arrest in MGC-803 and SGC-7901 cells, or mechanistically mediated by inhibiting Akt/NF- $\kappa \mathrm{B} /$ topoisomerase signaling. Therefore, our present study provides enhanced knowledge of the anticancer activity of SZC017 against gastric cancer cells.

\section{Materials and methods}

Chemicals and apparatus. All reagents and chemicals were obtained from standard commercial sources and used without further purification. Silica gel for column chromatography was purchased from Qingdao Haiyang Chemical Co. Ltd. NMR spectra were recorded on a Bruker DRX-400 with TMS as a reference. Electrospray ionization (ESI) mass spectra were recorded using an LC/Q-TOF MS spectrometer. Melting points 


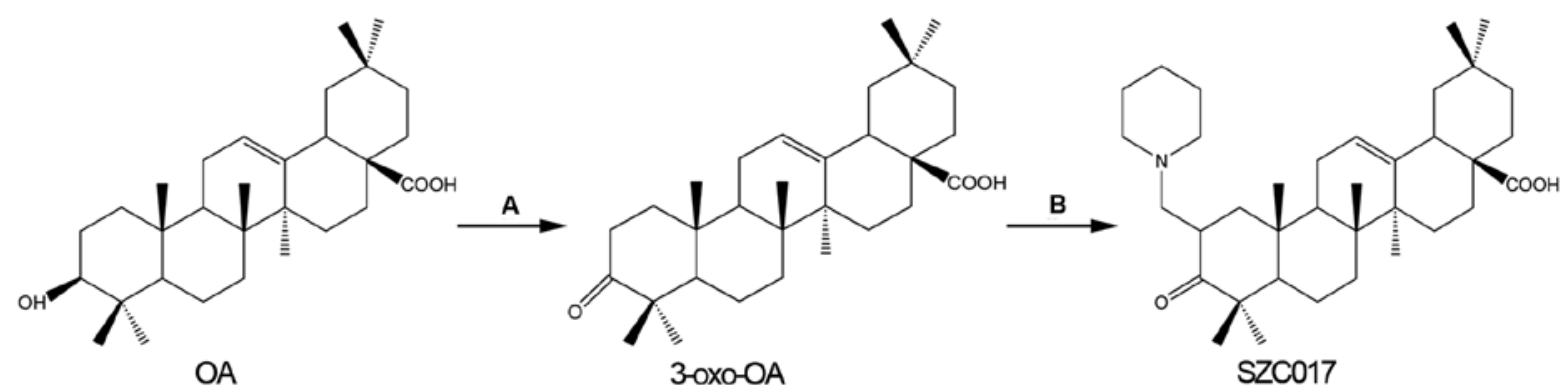

Figure 1. Synthesis of SZC017 [2-(piperidine-1-methyl)-3-oxo-olean-12-en-28-oic acid] via the Mannich reaction of 3-oxo-OA. (A) $\mathrm{CrO}_{3}, \mathrm{H}_{2} \mathrm{SO}_{4}$, dichloromethane/acetone, $\left(0^{\circ} \mathrm{C}, 30 \mathrm{~min}\right)$. (B) Piperidine hydrochloride, $\mathrm{SnCl}_{2}$, paraformaldehyde, ethanol, reflux $(20 \mathrm{~h})$.

were measured using X-4 Digital Micro Melting Point apparatus. 3-(4,5-Dimethylthiazol-2-yl)-2,5-diphenyltetrazolium bromide (MTT), penicillin and streptomycin were purchased from Sigma-Aldrich (St. Louis, MO, USA). Dulbecco's modified Eagle's medium (DMEM), trypsin-EDTA, and fetal bovine serum (FBS) were purchased from Gibco-BRL (Gaithersburg, MD, USA). The Annexin V-FITC apoptosis detection kit was purchased from Nanjing Jiancheng Bioengineering Institute (Nanjing, Jiangsu, China). Cell cycle and apoptosis analysis and the nuclear and cytoplasmic extraction kits were obtained from Beyotime Institute of Biotechnology (Haimen, Jiangsu, China). Antibodies to $\beta$-actin, histone H3, cleaved-PARP, procaspase-3, procaspase-9, Bax, Bcl-2, Akt, p-Akt, DNA topoisomerase I (Top-I, rabbit polyclonal) and DNA topoisomerase II $\alpha$ (Top-II $\alpha$, rabbit monoclonal) were purchased from Proteintech (Chicago, IL, USA). The primary antibodies against p-p65 (Ser536), p-IкB $\alpha$ (Ser32/Ser36) and the secondary antibody HRP goat anti-rabbit IgG were obtained from Abbkine (Redlands, CA, USA).

Synthesis of 3-oxo-olean-12-en-28-oic acid (3-oxo-OA) (Fig. 1A). OA $2.0 \mathrm{~g}(4.4 \mathrm{mmol})$ was dissolved in a $100-\mathrm{ml}$ mixed solvent of dichloromethane and acetone (volume ratio of 1:1). The solution was cooled to $0^{\circ} \mathrm{C}$, and $2.0 \mathrm{ml}$ Jones reagent was added dropwise within $30 \mathrm{~min}$. The reaction mixture was stirred for $30 \mathrm{~min}$ and $2 \mathrm{ml}$ isopropanol was added. After $10 \mathrm{~min}$, the mixture was filtered, and the filtrate was evaporated under reduced pressure to yield a solid residue, which was dissolved in $50 \mathrm{ml}$ ethyl acetate, and then washed with saturated brine $(50 \mathrm{ml} \times 3)$. The organic phase was dried with anhydrous sodium sulfate and concentrated in vacuo. The crude product was purified by silica gel column chromatography eluting with petroleum ether/ethyl acetate (20:1, v:v) to afford 3-oxo-OA as a white solid (1.97 g, 98.2\% yield). mp. 181-182 ${ }^{\circ} \mathrm{C}$. Positive ESI-TOF-MS: $\mathrm{m} / \mathrm{z} 499.2864[\mathrm{M}+2 \mathrm{Na}-\mathrm{H}]^{+}$. ${ }^{1} \mathrm{H}$ NMR $\left(\mathrm{CDCl}_{3}, 400 \mathrm{MHz}\right): 0.81,0.91,0.93,1.03,1.05,1.08$, 1.15 (each s, $\left.3 \mathrm{H}, 7 \mathrm{xCH}_{3}\right), 5.30(1 \mathrm{H}, \mathrm{t}, J=3.3 \mathrm{~Hz}, \mathrm{H}-12), 2.84$ (1H, dd, $J=13.6,3.8 \mathrm{~Hz}, \mathrm{H}-18), 2.33-2.55$ (2H, m, H-2).

Synthesis of 2-(piperidine-1-methyl)-3-oxo-olean-12-en28-oic acid (SZC017) (Fig. 1B). Piperidine hydrochloride $1.21 \mathrm{~g}$ (10.0 mmol), $\mathrm{SnCl}_{2} 0.38 \mathrm{~g}(2.0 \mathrm{mmol})$ and paraformaldehyde $0.3 \mathrm{~g}$ were added to a solution of 3-oxo-OA $(0.91 \mathrm{~g}, 2.0 \mathrm{mmol})$ in $40 \mathrm{ml}$ ethanol. The reaction mixture was heated at reflux for $20 \mathrm{~h}$ and then filtrated. The filtrate was concentrated to dryness under reduced pressure. The residue was dissolved in $200 \mathrm{ml}$ ethyl acetate, and then washed with saturated brine $(50 \mathrm{ml} \times 3)$. The organic layer was dried with anhydrous sodium sulfate and concentrated in vacuo. The crude product was purified by silica gel column chromatography eluting with chloroform/ethanol/water (15:1:0.1, v:v:v) to give compound SZC017 as a pale yellow solid $(0.18 \mathrm{~g}, 16.3 \%$ yield $)$. $\mathrm{mp} 198-200^{\circ} \mathrm{C}$. MS (TOF-ES positive) $\mathrm{m} / \mathrm{z}: 552.5[\mathrm{M}+\mathrm{H}]^{+} .{ }^{1} \mathrm{H}$ NMR $\left(\mathrm{CDCl}_{3}\right.$, $400 \mathrm{MHz}$ ): 0.82, 0.90, 0.94, 1.09, 1.10, 1.12, 1.38 (each s, 3H, 7x $\left.\mathrm{CH}_{3}\right), 1.86\left[\mathrm{~m}, 4 \mathrm{H}, \mathrm{N}\left(\mathrm{CH}_{2} \mathrm{CH}_{2}\right)_{2} \mathrm{CH}_{2}\right], 2.78\left(\mathrm{~m}, 1 \mathrm{H},-\mathrm{NCH}_{2}-\right)$, $2.84(\mathrm{~m}, 1 \mathrm{H}, \mathrm{H}-18), 2.86\left[\mathrm{~m}, 2 \mathrm{H}, \mathrm{N}\left(\mathrm{CH}_{2} \mathrm{CH}_{2}\right)_{2} \mathrm{CH}_{2}\right], 3.24$ (m, $1 \mathrm{H},-\mathrm{NCH} 2-), 3.59\left[\mathrm{~m}, 2 \mathrm{H}, \mathrm{N}\left(\mathrm{CH}_{2} \mathrm{CH}_{2}\right)_{2} \mathrm{CH}_{2}\right], 3.85(\mathrm{~m}, 1 \mathrm{H}$, $\mathrm{H}-2), 5.26(\mathrm{t}, 1 \mathrm{H}, J=3.3 \mathrm{~Hz}, \mathrm{H}-12)$.

Cell culture. Human gastric cancer cell lines MGC-803 and SGC-7901 were purchased from the Institute of Biochemistry Cell Biology (Shanghai, China). Cells were cultured in high-glucose DMEM containing 10\% FBS, $100 \mathrm{U} / \mathrm{ml}$ penicillin and $100 \mu \mathrm{g} / \mathrm{ml}$ streptomycin. Cells were maintained at $37^{\circ} \mathrm{C}$ in a humidified incubator of $5 \% \mathrm{CO}_{2}$.

MTT assay. Cells were seeded into 96-well plates and then cultured for $24 \mathrm{~h}$. After being exposed to SZC017 with different concentrations for the indicated time, $15 \mu \mathrm{l}$ MTT stock solution $(5 \mathrm{mg} / \mathrm{ml})$ was added into each well. After an additional 4-h incubation, $100 \mu \mathrm{l}$ SDS-isobutanol-HCl solution (10\% SDS, 5\% isobutanol and $12 \mathrm{mM} \mathrm{HCl}$ ) was added into each well. After an incubation at $37^{\circ} \mathrm{C}$ overnight, light absorption was detected at $570 \mathrm{~nm}$ using a microplate reader (Multiskan MK3; Shaanxi Pioneer Biotech Co., Ltd., Xi'an, China).

Cell apoptosis analysis. To determine whether apoptosis is involved in the inhibition of cell viability by SZC017 in the MGC-803 and SGC-7901 cells, the Annexin V-FITC apoptosis detection kit was performed. According to the manufacturer's instructions, the cells $\left(5 \times 10^{5}\right.$ cells $\left./ \mathrm{ml}\right)$ were seeded into 6-well plates with a further incubation overnight, and treated with different concentrations of SZC017 for $24 \mathrm{~h}$. Subsequently, the cells were collected and stained with Annexin V-FITC and propidium iodide (PI) for $30 \mathrm{~min}$ in the dark at room temperature. Finally, the samples were analyzed using FACScan flow cytometry (BD FACSAria II; BD Biosciences, Franklin Lakes, NJ, USA).

Cell cycle analysis. To evaluate the cell cycle distribution after exposure to SZC017, the cells were treated with different concentrations of SZC017 for $24 \mathrm{~h}$. After the treatment, the 

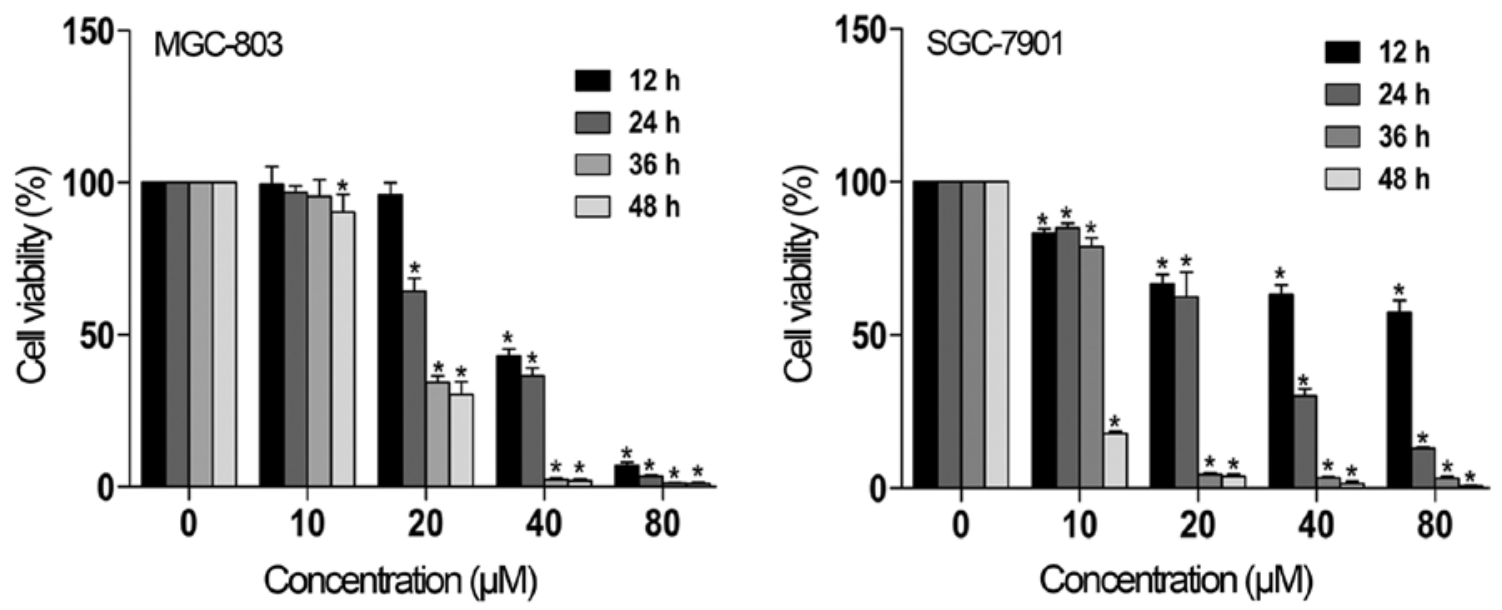

Figure 2. Inhibitory effect of SZC017 on the cell viability of SZC017 on MGC-803 cells in a concentration- and time-dependent manner. Both MGC-803 and SGC-7901 cells were treated with SZC017 at concentrations ranging from 10 to $80 \mu \mathrm{M}$, and cell viability was measured by MTT assay at the indicated time points, respectively. The values are expressed as mean \pm SD of three replicates. ${ }^{*}$ Significantly different from the control, $\mathrm{P}<0.05$.

cells were collected and fixed with $70 \%$ cold ethanol overnight at $4^{\circ} \mathrm{C}$. According to the manufacturer's instructions, PI staining reagent $(50 \mathrm{mg} / \mathrm{ml}$ PI and $1 \mathrm{mg} / \mathrm{ml}$ RNAse in $1 \mathrm{ml}$ of sodium citrate buffer, $\mathrm{pH}$ 7.4) was prepared, and the samples were then suspended with the reagent in the dark at $37^{\circ} \mathrm{C}$ for $30 \mathrm{~min}$. The cell cycle distribution was detected using FACScan flow cytometry (BD FACSAria II; BD Biosciences), and the data were analyzed using the multicycle program from Phoenix Flow Systems (San Diego, CA, USA).

Transmission electron microscopy (TEM). Cells were seeded into 6-well plates and then treated with SZC017 after a further 24-h incubation. After an additional 24-h incubation, the cells were collected and prefixed with $2.5 \%$ glutaraldehyde overnight at $4^{\circ} \mathrm{C}$. The cells were next post-fixed, dehydrated, embedded, sectioned, and stained as previously described (8). Finally, the electron micrographs were recorded using a transmission electron microscope (JEM-2000EX; Jeol Co., Ltd., Akishima, Japan).

Western blotting. Whole-cell lysates were prepared in an ice-cold lysis buffer containing $150 \mathrm{mM} \mathrm{NaCl}, 20 \mathrm{mM}$ Tris- $\mathrm{Cl}$ (pH 7.5), $1 \%$ Triton X-100, $1 \mathrm{mM}$ PMSF, $1 \mathrm{mM} \mathrm{Na} \mathrm{VO}_{4}, 25 \mathrm{mM} \mathrm{NaF}$, $1 \%$ aprotinin and $10 \mu \mathrm{g} / \mathrm{ml}$ leupeptin. Cytoplasmic and nuclear extracts were prepared using nuclear and cytoplasmic extraction kit according to the manufacturer's instructions. The extracts were fractionated by 10 or $12 \%$ SDS-polyacrylamide gel and then electrically transferred onto a polyvinylidene difluoride (PVDF) membrane. After blotting with TBST buffer [500 mM $\mathrm{NaCl}, 20 \mathrm{mM}$ Tris- $\mathrm{HCl}$ (pH 7.4), and 0.1\% Tween-20] containing $5 \%$ non-fat dry milk, the PVDF membrane was probed with the primary antibody $(1: 1,000)$ diluted in TBST buffer overnight at $4^{\circ} \mathrm{C}$ and then cultured with the secondary antibody $(1: 1,000)$ diluted in TBST for $1 \mathrm{~h}$ at room temperature. Membranes were then visualized using enhanced chemiluminescence reagent with LabWorks software (UVP, Upland, CA, USA).

Statisticalanalysis. Results are expressed as the mean \pm standard deviation (SD) of three replicates. The statistical significance between the control and the treatment groups was calculated using one-way ANOVA test and Tukey's multiple-comparison test. SPSS 17.0 software was used to analyze the data. $\mathrm{P}<0.05$ was considered to indicate a statistically significant difference.

\section{Results}

Effect of SZC017 on the cell viability of MGC-803 and SGC-7901 cells. To determine the effect of SZC017 on the cell viability of gastric cancer cells, gastric cancer cells were treated with different concentrations of SZC017, and cell viability was determined by MTT assay. As shown in Fig. 2, SZC017 decreased the cell viability of the MGC-803 and SGC-7901 cell lines in a time- and concentration-dependent manner. The $\mathrm{IC}_{50}$ value after $24 \mathrm{~h}$ of SZC017 treatment was $28.46 \mu \mathrm{M}$ for MGC-803 cells and $26.05 \mu \mathrm{M}$ for SGC-7901 cells. However, insignificant reductions in cell viability were observed after treatment with $10 \mu \mathrm{M} \mathrm{SZC017}$ for 12,24 and $36 \mathrm{~h}$ in the MGC-803 cells, as compared with the SGC-7901 cells. These findings indicate that SZC017 may be a potential compound against gastric cancer cells.

SZC017 induces apoptosis in the gastric cancer cells. Morphological changes of apoptosis, including cell shrinkage and fragmentation, were observed in both the MGC-803 and SGC-7901 cells after treatment with SZC017 (Fig. 3A). Whether the inhibition of cell viability of the gastric cancer cells by SZC017 was due to the induction of apoptosis was confirmed by flow cytometry. Our results showed that SZC017 induced apoptosis in the gastric cancer cells in a concentration-dependent manner. After treatment with different concentrations of SZC017 for $24 \mathrm{~h}$, the total apoptotic ratio was increased from 11.41 to $39.24 \%$ in the MGC-803 cells and from 3.33 to $31.04 \%$ in the SGC-7901 cells (Fig. 3B). Early apoptosis was induced by $\mathrm{SZC} 017$ in the MGC-803 cells, whereas late apoptosis was more obviously induced in the SGC-7901 cells (Fig. 3B). SZC017 treatment resulted in typical morphological changes in apoptosis, such as chromatin condensation, nuclear fragmentation and apoptosome formation (Fig. 3C). To determine whether intrinsic apoptosis is involved in SZC017-induced apoptosis in both cell lines, we next evaluated the expression of various 
A

A MGC-803 SZC017 $(\mu \mathrm{M})$
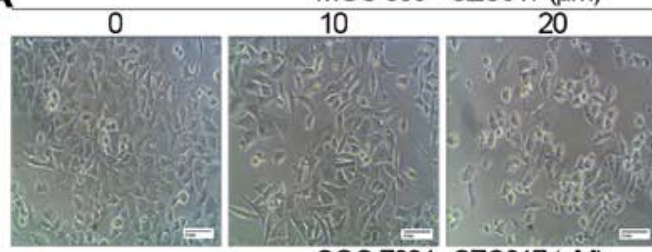

SGC-7901 SZC017( $\mu \mathrm{M})$
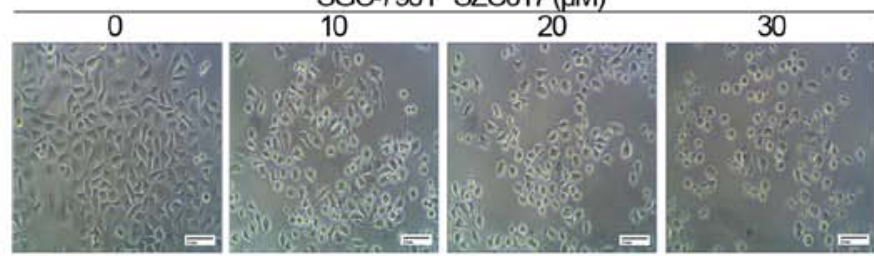

B

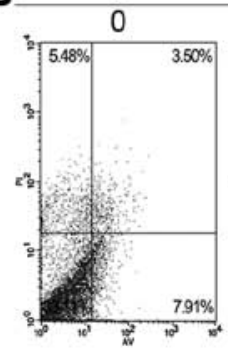

MGC-803 SZC017( $(\mu \mathrm{M})$
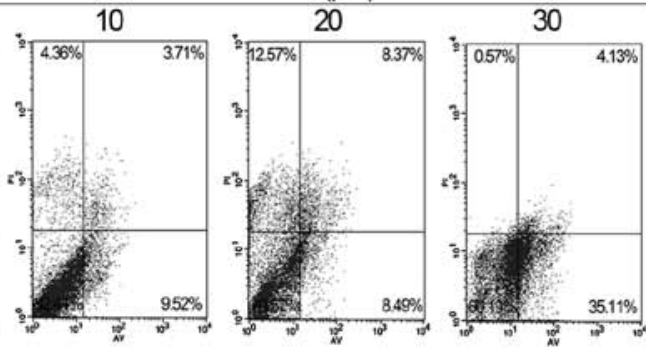

SZC017 (uM)
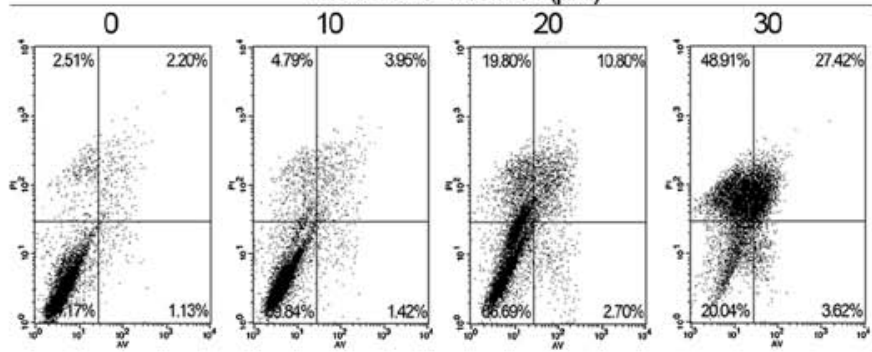

C MGC-803 SZCO17 ( $\mu \mathrm{M})$

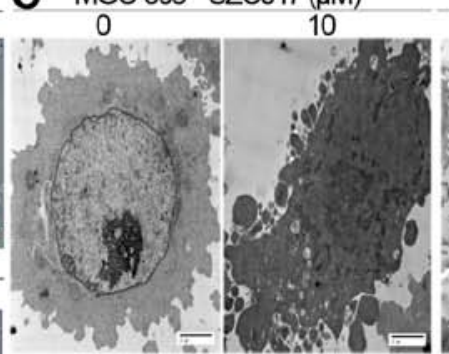

SGC-7901 SZC017 ( $\mu M)$
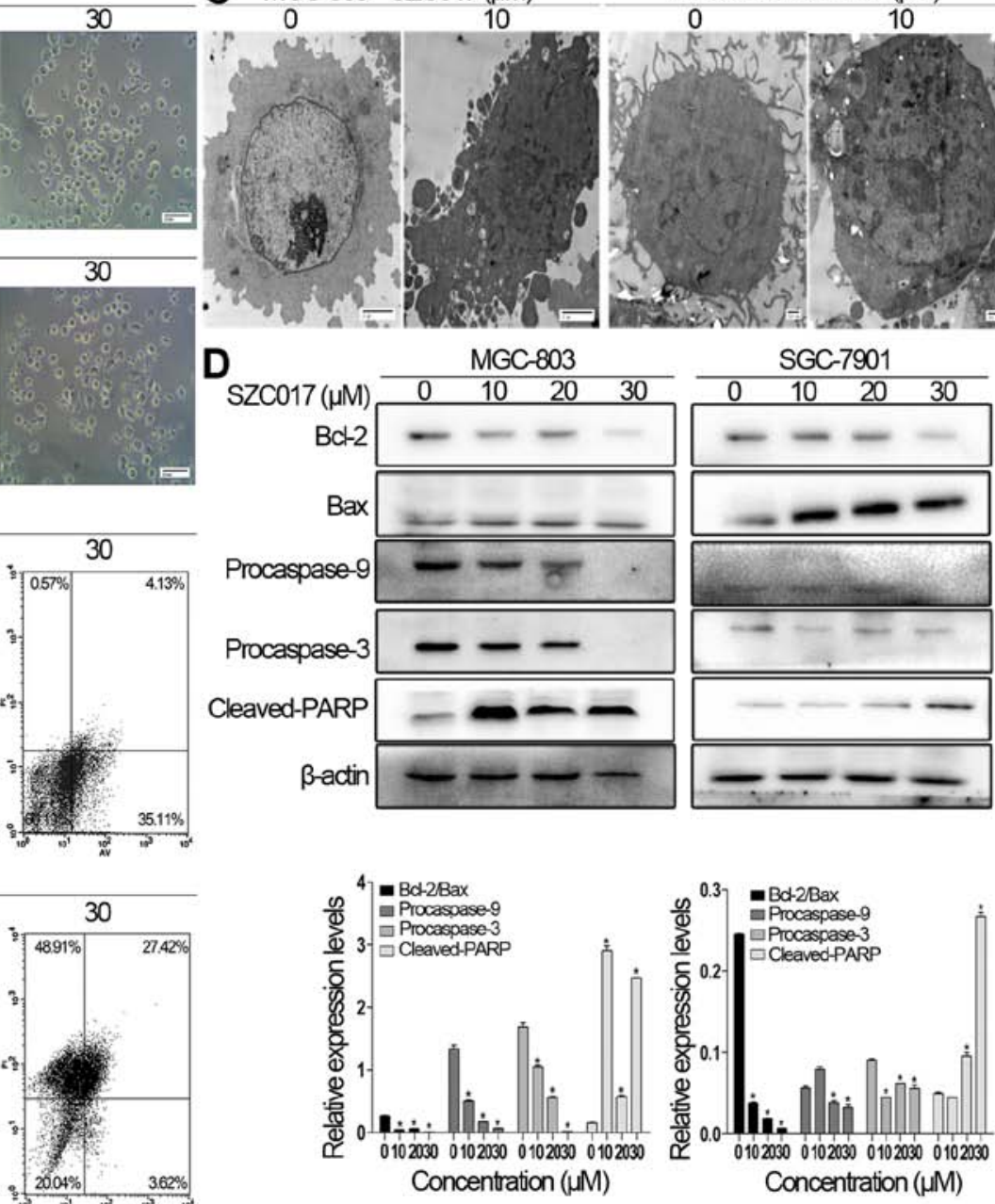

Figure 3. Apoptosis induction of SZC017 in the MGC-803 and SGC-7901 cells. (A) Inverted contrast phase microscopy shows morphological changes in the gastric cancer cells following treatment with SZC017 (10, 20 and $30 \mu \mathrm{M})$ for $24 \mathrm{~h}$. (B) Flow cytometric analysis of the apoptosis induction of SZC017 in the gastric cancer cells. After treatment with SZC017 at concentrations of 10, 20 and $30 \mu \mathrm{M}$ for $24 \mathrm{~h}$, the cells were then stained with Annexin V-FITC and PI and then analyzed by flow cytometry. (C) Transmission electron microscopy shows the occurrence of apoptosis in gastric cancer cells after treatment with $20 \mu \mathrm{M}$ SZC017 for $24 \mathrm{~h}$, respectively. (D) Western blot analysis was performed to determine the apoptosis pathway induced by SZC017 in the gastric cancer cells. Cells were treated with different concentrations of SZC017 (10, 20 and $30 \mu \mathrm{M})$ for $24 \mathrm{~h}$. The values are expressed as mean \pm SD of three replicates. *Significantly different from the control, $\mathrm{P}<0.05$.

intrinsic apoptosis-related proteins. The results showed that SZC017 induced intrinsic apoptosis in both cell lines. SZC017 significantly increased the expression of cleaved-PARP, which is an executioner and a hallmark of apoptosis (Fig. 3D) (9). As expected, the ratio of Bcl-2/Bax, which determines the susceptibility to apoptosis by regulating mitochondrial functions (10), was reduced by SZC017 (Fig. 3D). The levels of procaspase-9 and procaspase- 3 were also suppressed by SZC017 in both cell lines. Taken together, our findings indicate that SZC017 induced intrinsic apoptosis in the MGC-803 and SGC-7901 cells.

Effect of SZCO17 on cell cycle distribution of gastric cancer cells. Cell cycle arrest is an important mechanism that inhibits cancer cell growth (11). Our results revealed that SZC017 treatment caused an accumulation of SGC-7901 cells in the $\mathrm{S}$ phase. The percentage of cells in the $\mathrm{S}$ phase was increased from 31.99 in the control group to $45.86 \%$ in the $20 \mu \mathrm{M}$ SZC017 group (Fig. 4). However, no cell cycle arrest was observed in the MGC-803 cells after treatment with SZC017. Our findings suggest that SZC017 induced S phase arrest of the SGC-7901 cells, but had no effect on cell cycle distribution of the MGC-803 cells.

SZC017 inhibits Akt, NF- $\kappa B$ and topoisomerase signaling proteins. Chemotherapeutic compounds can induce cancer cell apoptosis via inhibition of the Akt signaling pathway $(12,13)$. Therefore, we first evaluated the levels of Akt and p-Akt of SZC017-treated gastric cancer cells. Fig. 5A clearly shows that the levels of Akt and p-Akt were suppressed by SZC017 in both cell lines. We next elucidated the effect of SZC017 on NF- $\kappa B$ signaling proteins in the gastric cancer cells. The results showed that the expression of $\mathrm{p}-\mathrm{I} \kappa \mathrm{B} \alpha$ in the cytoplasm, which is a key inhibitory protein in modulating NF- $\mathrm{kB}$ function (14), was reduced by SZC017 (Fig. 5B). Furthermore, a decrease in p-p65 in the cytoplasm and nucleus was also observed in both cell lines (Fig. 5B). DNA topoisomerase I (Top-I) and topoisomerase II $\alpha$ (Top-II $\alpha$ ) are effective targets for 
MGC-803 SZC017 ( $\mu \mathrm{M})$
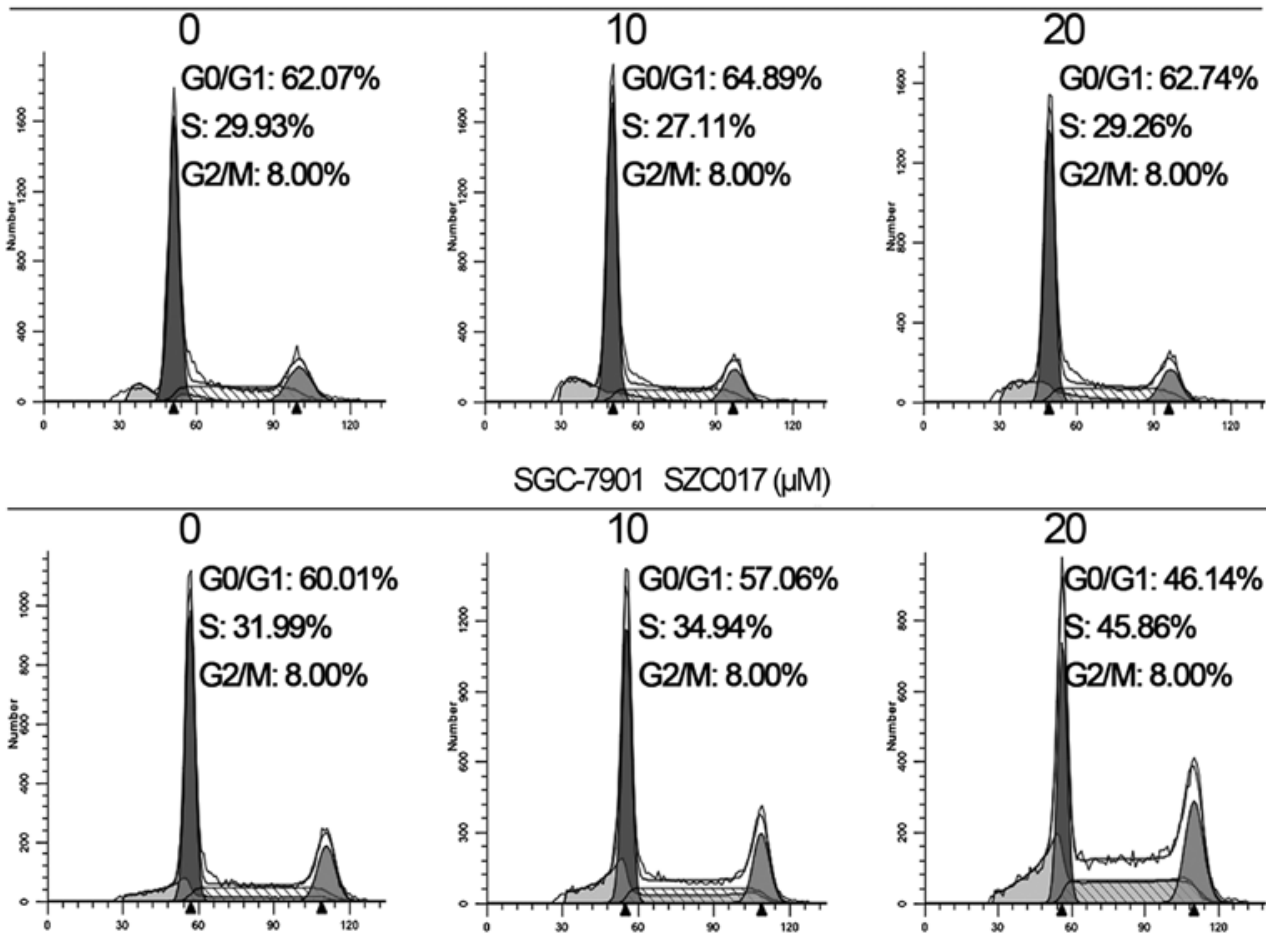

Figure 4. Cell cycle distribution of the SZC017-treated gastric cancer cells. Cells were exposed to SZC017 (10 and $20 \mu \mathrm{M})$ for $24 \mathrm{~h}$, and then cell cycle distribution was analyzed by flow cytometry.

chemotherapy which are tightly connected with the NF- $\mathrm{BB}$ pathway $(15,16)$. As expected, SZC017 decreased the expression of both Top-I and Top-II $\alpha$ in the nucleus in both cell lines, respectively (Fig. 5C). Taken together, our findings indicate that SZC017 is an effective compound against gastric cancer cells via targeting Akt/NF- $\mathrm{kB}$ signaling and Top-I and $-\mathrm{II} \alpha$.

\section{Discussion}

The present study demonstrated that SZC017, a novel derivative of OA, exhibited an anticancer effect against gastric cancer cells via induction of apoptosis, which was mainly mediated by inhibiting Akt/NF- $\mathrm{\kappa B}$ signaling and the targeting of Top-I and -II $\alpha$. SZC017-induced apoptosis of gastric cancer cells occurred via the intrinsic pathway, as manifested by a decreased expression of procaspase- 9 , procaspase- 3 and the ratio of $\mathrm{Bcl}-2 / \mathrm{Bax}$, and a increased expression of cleaved-PARP.

Dysregulated apoptosis and DNA damage response are two main characteristics of cancer cells and are the main causes of cancer therapy chemoresistance. Therefore, induction of apoptosis and cell cycle arrest are currently two essential mechanisms of anticancer drugs $(17,18)$. Apoptosis induction is a critical mechanism that decreases cell viability in gastric cancer cells, as evidenced by the presence of chromatin condensation, nuclear fragmentation and apoptosome formation (19), an increase in cleaved-PARP, an executioner of apoptosis (9), and flow cytometry analysis (Fig. 3). Many derivatives of $\mathrm{OA}$ induce cancer cell apoptosis via triggering intrinsic apoptosis pathway $(7,20-22)$, which is characterized by the release of cytochrome $c$ from the mitochondria through a decrease in the ratio of Bcl-2/Bax, interacting with apoptotic protease-activating factor 1 , activating procaspase-9, and finally activating procaspase- $3(18,19)$. Similarly, our results supported the above associated theory. Thus, the action of SZC017 was carried out by targeting the mitochondria and thereby leading to intrinsic apoptosis. Cell cycle arrest is considered to be another important mechanism for inhibiting cell viability (11). Interestingly, S phase arrest was observed after SZC017 treatment in SGC-7901 cells, whereas no effect on cell cycle distribution was presented in the MGC-803 cells suggesting that there are perhaps different mechanisms in regulating the cell cycle in these two cell lines.

Akt/NF- $\mathrm{kB}$ signaling is a major anti-apoptosis pathway for controlling cell survival and growth, and is frequently hyperactivated in cancer cells (23). OA and its several derivatives induce cancer cell apoptosis and show anticancer activity via inhibition of Akt and p-Akt $(6,13,24,25)$. Activated p-Akt promotes cancer cell survival via inactivation of downstream molecules such as procaspase-9 and Bad (26). During our observations, both Akt and p-Akt were significantly suppressed by SZC017 in the MGC-803 and SGC-7901 cell lines, and procaspase-9 was also inhibited suggesting that targeting the Akt pathway may be considered to be an effective mechanism in gastric cancer cells in response to SZC017 treatment.

$\mathrm{NF}-\mathrm{\kappa B}$ is a downstream molecule of Akt that can activate the NF- $\kappa B$ pathway through phosphorylation of I $\kappa B \alpha$. NF- $\kappa B$ can regulate several biological activities, including inflammation and apoptosis, and the NF- $\kappa \mathrm{B}$ pathway has been a pharmacological therapeutic and preventive target $(14,27)$. $\mathrm{NF}-\kappa \mathrm{B}$ complexes are usually located in the cytoplasm due to its connection with inhibitor protein $\mathrm{I} \kappa \mathrm{B} \alpha$. In the classical pathway, stimulation induces IKK activation leading to phosphorylation of IкB $\alpha$ which subsequently is ubiquitinated and degradated. After posttranslational modifications, the 
A
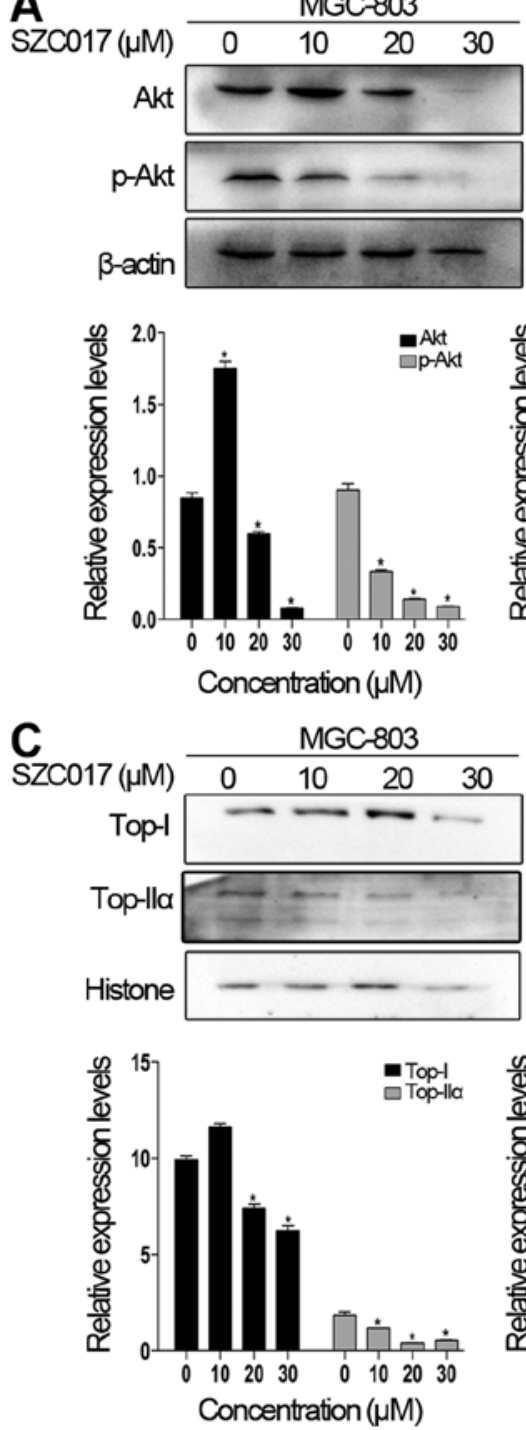
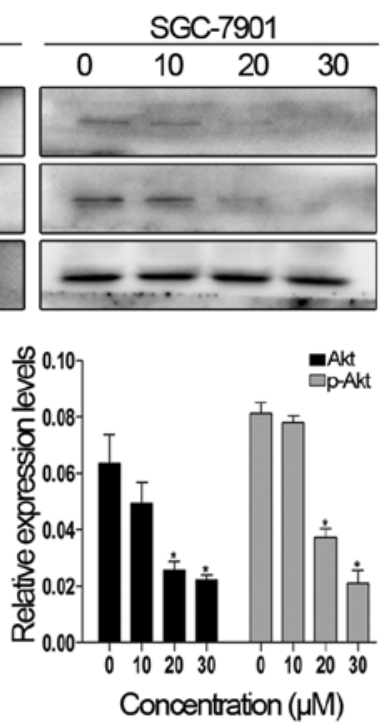

BZC017 ( $\mu \mathrm{M})$
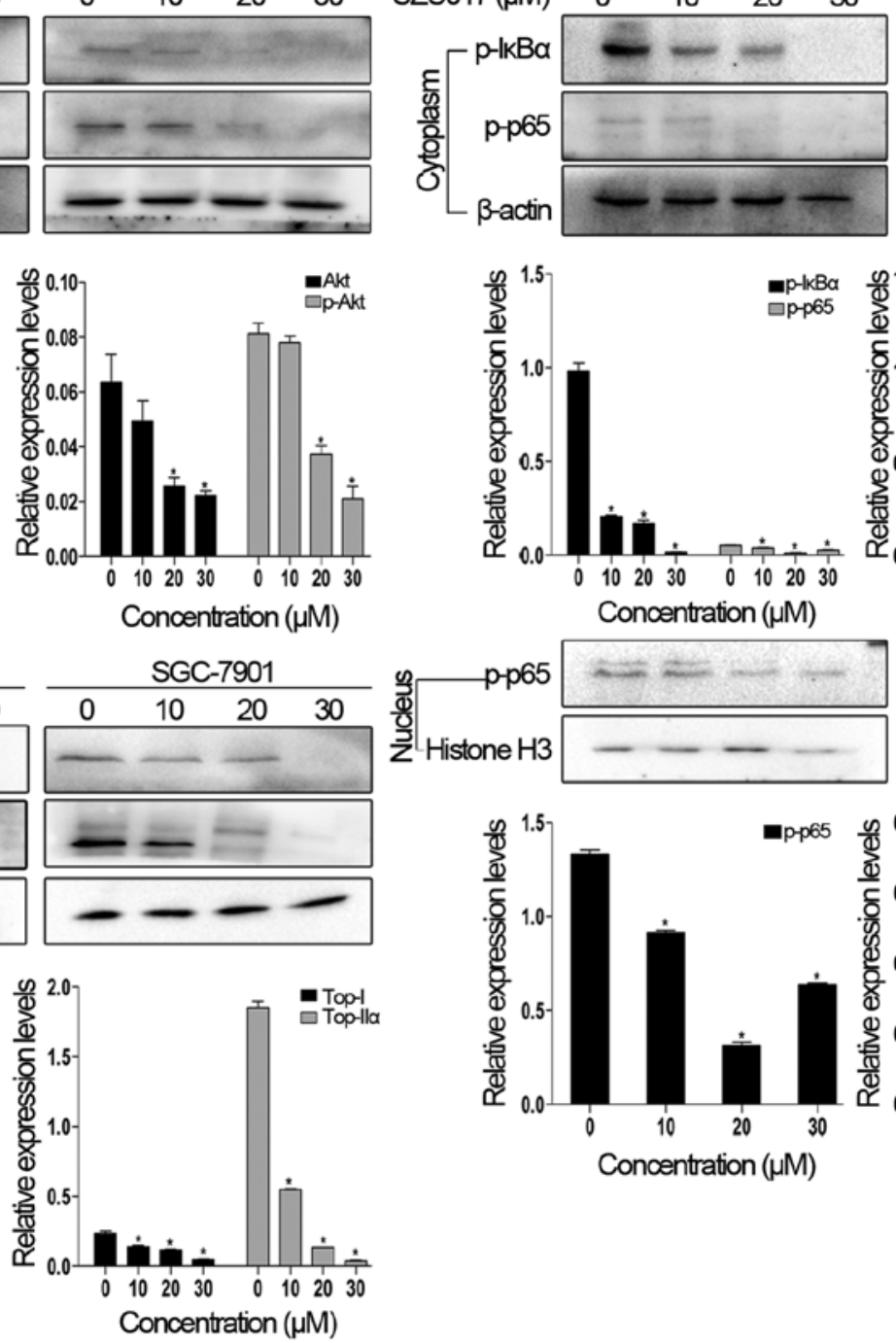

MGC-803

Conœntration $(\mu \mathrm{M})$

\begin{tabular}{llll}
\multicolumn{4}{c}{ SGC-7901 } \\
\hline 0 & 10 & 20 & 30 \\
\hline
\end{tabular}
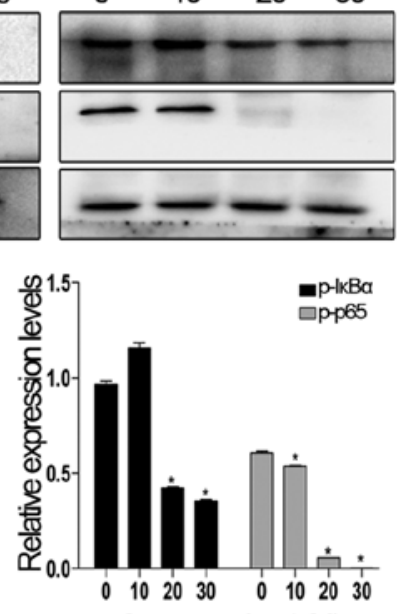

Concentration $(\mu \mathrm{M})$
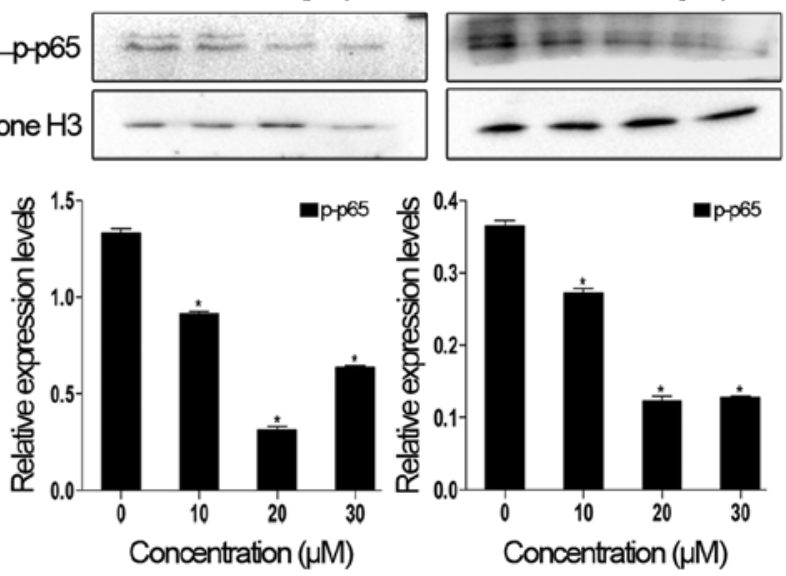

Figure 5. Effect of SZC017 on Akt, NF- $\mathrm{kB}$ and topoisomerase pathway-related proteins in the gastric cancer cells. Western blot analysis of several Akt/NF-кB and topoisomerase pathway-related proteins, including Akt, p-Akt, p-IкB $\alpha$, p-p65 in the cytoplasm and nucleus, and Top-I and Top-II $\alpha$. Treatment (24 h) of gastric cancer cells with SZC017 $(10,20$ and $30 \mu \mathrm{M})$ resulted in a change in the levels of these proteins in the gastric cancer cells. Data are expressed as mean \pm SD of three replicates. "Significantly different from the control, $\mathrm{P}<0.05$.

$\mathrm{NF}-\kappa \mathrm{B}$ dimer then translocates into the nucleus and binds to $\kappa \mathrm{B}$ sites to modulate specific gene expression $(14,28,29)$. There are two $\mathrm{I} \kappa \mathrm{B} \alpha$-related mechanisms for inhibiting the $\mathrm{NF}-\kappa \mathrm{B}$ pathway. Bortezomib, a clinical proteasome inhibitor, inhibits the NF- $\kappa$ B pathway in multiple myeloma cells via inhibition of proteasomes, stabilizing $\mathrm{I} \kappa \mathrm{B} \alpha$, and thus suppressing expression of p-p65 in the cytoplasm and its nuclear translocation $(30,31)$. Different from bortezomib, DETT, an anti-leishmanial thiadiazine agent, induces multiple myeloma cell apoptosis via suppression of p-p65 expression in the cytoplasm and its nuclear translocation, in addition to suppression of the phosphorylation of I $\mathrm{B} \alpha$ in the cytoplasm (32). Similar to DETT activity, inhibition of $\mathrm{p}-\mathrm{I} \kappa \mathrm{B} \alpha$ prevents $\mathrm{I} \kappa \mathrm{B} \alpha$ from degradation by proteasomes which is considered to be a critical step in suppressing the $\mathrm{NF}-\kappa \mathrm{B}$ pathway in gastric cancer cells after treatment with SZC017. Yet the effect of SZC017 on total $\mathrm{I} \kappa \mathrm{B} \alpha$ requires further investigation. The inhibition of the NF- $\kappa \mathrm{B}$ pathway by bortezomib is implemented through the stabilization of $\mathrm{p}-\mathrm{I} \kappa \mathrm{B} \alpha$ from degradation by the proteasome, while SZC017 and DETT decrease $\mathrm{p}-\mathrm{I} \kappa \mathrm{B} \alpha$ and thus prevent $\mathrm{I} \kappa \mathrm{B} \alpha$ from degradation. Although the effects of SZC017, DETT and bortezomib on the $\mathrm{NF}-\kappa \mathrm{B}$ pathway are distinct in terms of $\mathrm{p}-\mathrm{I} \kappa \mathrm{B} \alpha$, the final effect is the same. Phosphorylation of p65 at Ser536 facilitates p65 nuclear translocation and DNA binding, which in turn modulates downstream gene expression (33). p-p65-dependent $\mathrm{NF}-\kappa \mathrm{B}$ pathway activation is considered to play a critical role in cancer cell survival (32). To determine whether SZC017 inhibits p-p65 activity, we evaluated the expression of p-p65 in both the cytoplasm and nucleus, respectively. Our findings indicated that SZC017 first suppressed $\mathrm{p}-\mathrm{I} \kappa \mathrm{B} \alpha$, and then inhibited p-p65 expression in the cytoplasm and nucleus in gastric cancer cells and thereby led to the inhibition of the $\mathrm{NF}-\kappa \mathrm{B}$ pathway. Nuclear translocation of $\mathrm{NF}-\kappa \mathrm{B}$ complexes is an important aspect of NF- $\kappa \mathrm{B}$ activation. However, additional posttranslational modifications of NF- $\kappa \mathrm{B}$ itself is also critical in regulating the downstream gene expression $(34,35)$. Taken 
together, the suppression of $\mathrm{p}-\mathrm{I} \kappa \mathrm{B} \alpha$ and $\mathrm{p}-\mathrm{p} 65$ in the cytoplasm and nucleus contributes to inhibition of the NF- $\kappa \mathrm{B}$ pathway in SZC017-treated gastric cancer cells.

Recent research demonstrates that topoisomerase-targeting drugs activate the $\mathrm{NF}-\kappa \mathrm{B}$ pathway, and thus lead to chemoresistance. In patients with colorectal cancer, CPT-11 (irinotecan), a topoisomerase inhibitor, can induce chemoresistance in malignant cells via activation of the NF- $\kappa \mathrm{B}$ pathway (36-38). DNA topoisomerases are molecules that modulate chromosome superstructure and integrity via cutting, shuffling DNA strands, removing DNA supercoils, and disentangling snarled DNA segments (39). DNA topoisomerase I (Top-I) and topoisomerase II $\alpha$ (Top-II $\alpha$ ) are effective targets for chemotherapy $(15,16,40)$. Our results indicate that Top-I and Top-II $\alpha$ are effective targets in SZC017 against gastric cancer cells. Interestingly, different from CPT-11, SZC017 suppressed the level of Top-I and Top-II $\alpha$, and inhibited the NF- $\kappa$ B pathway in a $\mathrm{p}-\mathrm{I} \kappa \mathrm{B} \alpha$ and $\mathrm{p}$-p65-dependent manner. Therefore, our findings suggest that SZC017 may be an effective anticancer agent in terms of its inhibitiory function of both the Akt/NF- $\kappa \mathrm{B}$ pathway and topoisomerases (Top-I and Top-II $\alpha$ ).

In the present study, we demonstrated that SZC017, a novel derivative of $\mathrm{OA}$, possessed a potential anticancer effect against gastric cancer cells via induction of intrinsic apoptosis, inhibition of Akt/NF- $\kappa \mathrm{B}$ signaling, and targeting of Top-I and $-\mathrm{II} \alpha$ proteins. Therefore, our data revealed a potential chemotherapeutic agent for inducing gastric cancer cell death. However, further research on the effect of SZC017 on other cancer types warrants investigation.

\section{Acknowledgements}

The present study was supported by the Natural Science Foundation of China (no. 30772601) and the University Innovation Team Project Foundation of the Education Department of Liaoning (no. LT2013019).

\section{References}

1. Torre LA, Bray F, Siegel RL, Ferlay J, Lortet-Tieulent J and Jemal A: Global cancer statistics, 2012. CA Cancer J Clin 65: $87-108,2015$.

2. Liby KT, Yore MM and Sporn MB: Triterpenoids and rexinoids as multifunctional agents for the prevention and treatment of cancer. Nat Rev Cancer 7: 357-369, 2007.

3. Pollier J and Goossens A: Oleanolic acid. Phytochemistry 77: $10-15,2012$.

4. Shanmugam MK, Dai X, Kumar AP, Tan BK, Sethi G and Bishayee A: Oleanolic acid and its synthetic derivatives for the prevention and therapy of cancer: Preclinical and clinical evidence. Cancer Lett 346: 206-216, 2014.

5. Bishayee A, Mandal A, Thoppil RJ, Darvesh AS and Bhatia D: Chemopreventive effect of a novel oleanane triterpenoid in a chemically induced rodent model of breast cancer. Int J Cancer 133: 1054-1063, 2013.

6. Deeb D, Gao X, Liu Y, Jiang D, Divine GW, Arbab AS, Dulchavsky SA and Gautam SC: Synthetic triterpenoid CDDO prevents the progression and metastasis of prostate cancer in TRAMP mice by inhibiting survival signaling. Carcinogenesis 32: 757-764, 2011.

7. Konopleva M, Contractor R, Kurinna SM, Chen W, Andreeff M and Ruvolo PP: The novel triterpenoid CDDO-Me suppresses MAPK pathways and promotes p38 activation in acute myeloid leukemia cells. Leukemia 19: 1350-1354, 2005.

8. Shao Y, Gao Z, Marks PA and Jiang X: Apoptotic and autophagic cell death induced by histone deacetylase inhibitors. Proc Natl Acad Sci USA 101: 18030-18035, 2004.
9. Boucher D, Blais V and Denault JB: Caspase-7 uses an exosite to promote poly(ADP ribose) polymerase 1 proteolysis. Proc Natl Acad Sci USA 109: 5669-5674, 2012.

10. Cory $\mathrm{S}$ and Adams JM: Killing cancer cells by flipping the Bcl-2/Bax switch. Cancer Cell 8: 5-6, 2005.

11. Qiu P, Guan H, Dong P, Li S, Ho CT, Pan MH, McClements DJ and Xiao H: The p53-, Bax- and p21-dependent inhibition of colon cancer cell growth by 5-hydroxy polymethoxyflavones. Mol Nutr Food Res 55: 613-622, 2011.

12. Kim W, Yang HJ, Youn H, Yun YJ, Seong KM and Youn B: Myricetin inhibits Akt survival signaling and induces Bad-mediated apoptosis in a low dose ultraviolet (UV)-B-irradiated HaCaT human immortalized keratinocytes. J Radiat Res (Tokyo) 51: 285-296, 2010.

13. Wang X, Bai H, Zhang X, Liu J, Cao P, Liao N, Zhang W, Wang Z and Hai C: Inhibitory effect of oleanolic acid on hepatocellular carcinoma via ERK-p53-mediated cell cycle arrest and mitochondrial-dependent apoptosis. Carcinogenesis 34: 1323-1330, 2013.

14. Gilmore TD and Herscovitch M: Inhibitors of NF-kappaB signaling: 785 and counting. Oncogene 25: 6887-6899, 2006.

15. Li TK and Liu LF: Tumor cell death induced by topoisomerase-targeting drugs. Annu Rev Pharmacol Toxicol 41: 53-77, 2001.

16. Nitiss JL: DNA topoisomerase II and its growing repertoire of biological functions. Nat Rev Cancer 9: 327-337, 2009.

17. Curtin NJ: Inhibiting the DNA damage response as a therapeutic manoeuvre in cancer. Br J Pharmacol 169: 1745-1765, 2013.

18. Ghavami S, Hashemi M, Ande SR, Yeganeh B, Xiao W, Eshraghi M, Bus CJ, Kadkhoda K, Wiechec E, Halayko AJ, et al: Apoptosis and cancer: Mutations within caspase genes. J Med Genet 46: 497-510, 2009.

19. Call JA, Eckhardt SG and Camidge DR: Targeted manipulation of apoptosis in cancer treatment. Lancet Oncol 9: 1002-1011, 2008.

20. Ravanan P, Sano R, Talwar P, Ogasawara S, Matsuzawa S, Cuddy M, Singh SK, Rao GS, Kondaiah P and Reed JC: Synthetic triterpenoid cyano enone of methyl boswellate activates intrinsic, extrinsic, and endoplasmic reticulum stress cell death pathways in tumor cell lines. Mol Cancer Ther 10: 1635-1643, 2011.

21. Hyer ML, Shi R, Krajewska M, Meyer C, Lebedeva IV, Fisher PB and Reed JC: Apoptotic activity and mechanism of 2-cyano-3, 12-dioxoolean-1,9-dien-28-oic-acid and related synthetic triterpenoids in prostate cancer. Cancer Res 68: 2927-2933, 2008.

22. Inoue S, Snowden RT, Dyer MJ and Cohen GM: CDDO induces apoptosis via the intrinsic pathway in lymphoid cells. Leukemia 18: 948-952, 2004.

23. Altomare DA and Testa JR: Perturbations of the AKT signaling pathway in human cancer. Oncogene 24: 7455-7464, 2005.

24. Ling X, Konopleva M,Zeng Z, Ruvolo V, Stephens LC, Schober W, McQueen T, Dietrich M, Madden TL and Andreeff M: The novel triterpenoid C-28 methyl ester of 2-cyano-3, 12-dioxoolen-1, 9-dien-28-oic acid inhibits metastatic murine breast tumor growth through inactivation of STAT3 signaling. Cancer Res 67: 4210-4218, 2007.

25. Dai S, Zheng Y, Chen B, Gao M, Zhang Y, Zhang L, Gong W and He F: Two Gln187 mutants of human soluble APRIL inhibit proliferation of lung carcinoma A549 cells. Acta Biochim Pol 56: 703-710, 2009

26. Datta SR, Dudek H, Tao X, Masters S, Fu H, Gotoh Y and Greenberg ME: Akt phosphorylation of BAD couples survival signals to the cell-intrinsic death machinery. Cell 91: 231-241, 1997.

27. Ahmad A, Biersack B,Li Y, Kong D, Bao B,Schobert R, Padhye SB and Sarkar FH: Targeted regulation of PI3K/Akt/mTOR/NF-kB signaling by indole compounds and their derivatives: Mechanistic details and biological implications for cancer therapy. Anticancer Agents Med Chem 13: 1002-1013, 2013.

28. Hayden MS and Ghosh S: Shared principles in NF-kappaB signaling. Cell 132: 344-362, 2008.

29. Tully JE, Nolin JD, Guala AS, Hoffman SM, Roberson EC, Lahue KG, van der Velden J, Anathy V, Blackwell TS and Janssen-Heininger YM: Cooperation between classical and alternative $\mathrm{NF}-\mathrm{\kappa B}$ pathways regulates proinflammatory responses in epithelial cells. Am J Respir Cell Mol Biol 47: 497-508, 2012.

30. Manna S, Singha B, Phyo SA, Gatla HR, Chang TP, Sanacora S, Ramaswami S and Vancurova I: Proteasome inhibition by bortezomib increases IL-8 expression in androgen-independent prostate cancer cells: the role of IKKalpha. J Immunol 191: 2837-2846, 2013.

31. Murray RZ and Norbury C: Proteasome inhibitors as anti-cancer agents. Anticancer Drugs 11: 407-417, 2000. 
32. Chen G, Han K, Xu X, Du X, Zhang Z, Tang J, Shi M, Wang M, Li J, Cao B, et al: An anti-leishmanial thiadiazine agent induces multiple myeloma cell apoptosis by suppressing the nuclear factor kappaB signalling pathway. Br J Cancer 110: 63-70, 2014.

33. Buss H, Dörrie A, Schmitz ML, Hoffmann E, Resch K and Kracht M: Constitutive and interleukin-1-inducible phosphorylation of $\mathrm{p} 65 \mathrm{NF}-\mathrm{\kappa B}$ at serine 536 is mediated by multiple protein kinases including I $\kappa$ B kinase (IKK)- $\alpha$, IKK $\beta$, IKK $\varepsilon$, TRAF family member-associated (TANK)-binding kinase 1 (TBK1), and an unknown kinase and couples p65 to TATA-binding protein-associated factor II31-mediated interleukin- 8 transcription. J Biol Chem 279: 55633-55643, 2004.

34. Deng WG, Zhu Y and Wu KK: Up-regulation of p300 binding and p50 acetylation in tumor necrosis factor-alpha-induced cyclooxygenase-2 promoter activation. J Biol Chem 278: 4770-4777, 2003

35. Zhong H, SuYang H, Erdjument-Bromage H, Tempst $\mathrm{P}$ and Ghosh S: The transcriptional activity of NF-kappaB is regulated by the IkappaB-associated PKAc subunit through a cyclic AMP-independent mechanism. Cell 89: 413-424, 1997.
36. Lagadec P, Griessinger E, Nawrot MP, Fenouille N, Colosetti P, Imbert V, Mari M, Hofman P, Czerucka D, Rousseau D, et al: Pharmacological targeting of NF-kappaB potentiates the effect of the topoisomerase inhibitor CPT-11 on colon cancer cells. Br J Cancer 98: 335-344, 2008.

37. Nakanishi $\mathrm{C}$ and Toi M: Nuclear factor-kappaB inhibitors as sensitizers to anticancer drugs. Nat Rev Cancer 5: 297-309, 2005.

38. $\mathrm{Xu} \mathrm{Y}$ and Villalona-Calero MA: Irinotecan: Mechanisms of tumor resistance and novel strategies for modulating its activity. Ann Oncol 13: 1841-1851, 2002.

39. Vos SM, Tretter EM, Schmidt BH and Berger JM: All tangled up: How cells direct, manage and exploit topoisomerase function. Nat Rev Mol Cell Biol 12: 827-841, 2011.

40. Pommier Y: Topoisomerase I inhibitors: Camptothecins and beyond. Nat Rev Cancer 6: 789-802, 2006. 